\title{
Comparative Analysis of DNA Barcoding and HPLC Fingerprint to Trace Species of Phellodendri Cortex, an Important Traditional Chinese Medicine from Multiple Sources
}

\author{
Zhipeng Zhang, Yang Zhang, Zhao Zhang,* Hui Yao, Haitao Liu, Ben'gang Zhang, and \\ Yonghong Liao \\ Key Laboratory of Bioactive Substances and Resources Utilization of Chinese Herbal Medicine, Ministry of \\ Education/Institute of Medicinal Plant Development, Chinese Academy of Medical Sciences, Peking Union Medical \\ College; No. 151, Malianwa North Road, Haidian District, Beijing 100193, P. R. China. \\ Received February 29, 2016; accepted May 24, 2016; advance publication released online June 7, 2016
}

\begin{abstract}
Phellodendri Cortex is derived from the dried barks of Phellodendron genus species, has been extensively used in traditional Chinese medicine. The cortex is divided into two odorless crude drugs Guanhuangbo and Huangbo. Historically, it has been difficult to distinguish their identities due to a lack of identification methods. This study was executed to confirm the identity and to ensure the species traceability of Phellodendri Cortex. In the current study, analysis is based on the internal transcribed spacer (ITS) and $p s b \mathrm{~A}-t r n \mathrm{H}$ intergenic spacer ( $p s b \mathrm{~A}-t r n \mathrm{H})$ barcodes and HPLC fingerprint was carried out to guarantee the species traceability of Guanhuangbo and Huangbo. DNA barcoding data successfully identified the three plants of the Phellodendron genus species by ITS $+p s b \mathrm{~A}-t r n \mathrm{H}$, with the ability to distinguish the species origin of Huangbo. Moreover, the psbA-trn $\mathrm{H}$ data distinguished Guanhuangbo and Huangbo except to trace species. The HPLC fingerprint data showed that Guanhuangbo was clearly different from Huangbo, but there was no difference between the two origins of Huangbo. Additionally, the result of hierarchical clustering analysis, based on chlorogenic acid, phellodendrine, magnoflorine, jatrorrhizine, palmatine and berberine, was consistent with the HPLC fingerprint analysis. These results show that DNA barcoding and HPLC fingerprint can discriminate Guanhuangbo and Huangbo. However, DNA barcoding is more powerful than HPLC fingerprint for species traceability in the identification of related species that are genetically similar. DNA barcoding is a useful scientific tool to accurately confirm the identities of medicinal materials from multiple sources.
\end{abstract}

Key words Phellodendri Cortex; DNA barcoding; HPLC fingerprint; species traceability

Phellodendri Cortex is derived from the dried barks of Phellodendron amurense RuPR., Phellodendron chinense SCHNEID. and the variant Phellodendron chinense var. glabriusculum SchNeID. (Rutaceae). ${ }^{1)}$ It is commonly used in traditional oriental medicine, and it has demonstrated a wide range of biological and pharmacological activities - antimicrobial, anti-inflammatory and anticancer-in numerous studies. ${ }^{2,3}$ In the Chinese Pharmacopoeia (2000 version), P. amurense and $P$. chinense are listed as the original plants of Phellodendri Cortex. ${ }^{4)}$ However, $P$. amurense is listed as an endangered species and is strictly protected by law because this resource has decreased dramatically. ${ }^{5}$ Additionally, there are differences between $P$. amurense and $P$. chinense regarding plant morphology and chemical composition. Thus, to control the quality of the herb and to protect the wild resource of $P$. amurense, Phellodendri Cortex is officially listed in the Chinese Pharmacopoeia (2005 version) as two different crude drugs, Guanhuangbo and Huangbo. ${ }^{6}$ Guanhuangbo is derived from the $P$. amurense bark, while Huangbo is derived from the $P$. chinense bark. Since the wild resource of $P$. chinense is insufficient, the cultivated herb of $P$. chinense var. glabriusculum is also utilized in the production of crude drugs. However, the three cortexes of $P$. amurense, $P$. chinense and $P$. chinense var. glabriusculum are odorless, and there has been difficulty in differentiating their identities due to a lack of identification methods.

In the Chinese Pharmacopoeia, the quality control of Phellodendri Cortex includes a confirmation of identity and an evaluation of the content of chemical markers. The identity of Guanhuangbo is confirmed by the presence of obacunone using the thin-layer chromatography (TLC) method, and its quantity is determined by measuring the content of berberine chloride and palmatine chloride using the HPLC method; Huangbo is identified by the presence of phellodendrine, and its quantity is determined by measuring the content of berberine chloride and phellodendrine chloride. ${ }^{7)}$ However, the two crude herbs contain both obacunone and phellodendrine, making the TLC method insufficient. Traditional methods for quality control of Phellodendri Cortex include TLC, high performance capillary electrophoresis (HPCE), HPLC and random amplified polymorphic DNA (RAPD). ${ }^{8-11)}$ These previous studies have successfully determined the content of chlorogenic acid, phellodendrine, magnoflorine, jatrorrhizine, palmatine and berberine for quality evaluation of Guanhuangbo using the HPLC method, and they have confirmed the polymorphisms of Guanhuangbo and Huangbo in 12 primers using the RAPD method. ${ }^{11,12)}$ However, these methods are still inadequate for distinguishing the identity and for tracing the species of Phellodendri Cortex.

DNA barcoding is an emerging technology for modern species identification and has drawn increasing attention. ${ }^{13)}$ In 2009, the Consortium for the Barcode of Life recommended the ribulose bisphosphate carboxylase large chain ( $\mathrm{rbcL}$ ) and maturase $\mathrm{K}$ (matK) genes as core DNA barcoding of the seed plant and the $p s b \mathrm{~A}-\operatorname{trn} \mathrm{H}$ intergenic spacer $(p s b \mathrm{~A}-t r n \mathrm{H})$ and internal transcribed spacer (ITS) genes as supplementary 
DNA barcoding. ${ }^{14)}$ In 2011, the Chinese Plant Barcode of Life Group proposed ITS/ITS2 as the core DNA barcoding for the seed plant. ${ }^{15)}$ DNA barcoding has since been successfully applied towards the traceability of many herb medicines. ${ }^{16-22)}$ Additional candidate DNA barcoding genes in seed plants, which are used for identification of Chinese medicines and to confirm the identities of the original plants, are currently providing a basis for identifying Phellodendri Cortex.

For the quality control of crude drugs and the protection of the endangered species in the wild, it is highly desirable to confirm the identities of crude drugs and to ensure the species traceability of Phellodendri Cortex. In this study, we collected 32 samples including $P$. amurense, $P$. chinense and $P$. chinense var. glabriusculum. from 15 areas. We performed experiments to differentiate the crude herbs using ITS-PCR and psbA-trn H-PCR and to quantify 6 chemical markers using the HPLC/photodiode array detector (PAD) method, with the intent to establish a method that enables the species traceability of Phellodendri Cortex.

\section{MATERIALS AND METHODS}

Sampling of Plant Materials Thirty-two samples were collected from the Liaoning, Jilin, Heilongjiang, Hebei, Bei- jing, Sichuan, Chongqing and Hubei provinces in China to ensure a sufficient representation of the herbs. Among the samples, thirteen were $P$. amurense (11 cortex and 2 leaf samples), six were $P$. chinense (5 cortex and 1 leaf samples) and nine were $P$. chinense var. glabriusculum (6 cortex and 3 leaf samples). Additionally, 4 leaf samples of Tetradium ruticarpum with a closer genetic relationship to the Phellodendron genus were collected as the outgroup for the molecular analysis (Table 1). The botanical identities of the stems were confirmed by Professor Zhao Zhang. All corresponding voucher samples were deposited in the Herbarium of the Institute of Medicinal Plant Development.

DNA Barcoding All samples taken from the dried cortex or leaf $(40 \mathrm{mg})$ were rubbed for two minutes at a frequency of $30 \mathrm{r} / \mathrm{s}$. Total genomic DNA was extracted using the Plant Genomic DNA Kit (Tiangen Biotech Co., China) according to the manufacturer's instructions. The extracted genomic DNA was amplified by polymerase chain reaction (PCR), using the ITS (ITS5F, 5'-GGA AGT AAA AGT CGT AAC AAGG-3' and ITS4R， 5'-TCC TCCGCT TAT TGATATGC-3') and psbA$\operatorname{trn\mathrm {H}}$ (fwdPA, 5'-GTT ATGCATGAACGT AATGCT-3' and revTH, 5'-CGC GCA TGG TGG ATT CAC AAT CC-3') primers. PCR reaction mixtures contained $2 \mu \mathrm{L}$ DNA template, $8.5 \mu \mathrm{L}$ $\mathrm{ddH}_{2} \mathrm{O}, 12.5 \mu \mathrm{L} 2 \times \mathrm{Taq}$ PCR Master Mix (Beijing TransGen

Table 1. Plant Materials Examined in This Study

\begin{tabular}{|c|c|c|c|c|c|c|}
\hline \multirow{2}{*}{ Codes } & \multirow{2}{*}{ Samples } & \multirow{2}{*}{ Scientific name } & \multirow{2}{*}{ Family } & \multirow{2}{*}{ Localities } & \multicolumn{2}{|c|}{ GenBank accession No. } \\
\hline & & & & & ITS & $p s b \mathrm{~A}-t r n \mathrm{H}$ \\
\hline $\mathrm{S} 1$ & Cortex & P. amurense & Rutaceae & Liaoning, China & KT961044 & KT961071 \\
\hline $\mathrm{S} 2$ & Cortex & P. amurense & Rutaceae & Jilin, China & KT961045 & KT961073 \\
\hline $\mathrm{S} 3$ & Cortex & P. amurense & Rutaceae & Jilin, China & KT961039 & KT961072 \\
\hline S4 & Cortex & P. amurense & Rutaceae & Jilin, China & KT961046 & KT961074 \\
\hline S5 & Cortex & P. amurense & Rutaceae & Jilin, China & KT961047 & KT961075 \\
\hline S6 & Cortex & P. amurense & Rutaceae & Heilongjiang, China & KT961048 & KT961076 \\
\hline S7 & Cortex & P. amurense & Rutaceae & Heilongjiang, China & КT961049 & KT961077 \\
\hline S8 & Cortex & P. amurense & Rutaceae & Heilongjiang, China & КТ961050 & KT961078 \\
\hline S9 & Cortex & P. amurense & Rutaceae & Heilongjiang, China & KT961051 & KT961079 \\
\hline $\mathrm{S} 10$ & Cortex & $P$. amurense & Rutaceae & Beijing, China & KT961054 & KT961082 \\
\hline S11 & Cortex & P. amurense & Rutaceae & Beijing, China & KT961055 & KT961083 \\
\hline L1 & Leaf & P. amurense & Rutaceae & Hebei, China & КT961052 & KT961080 \\
\hline L2 & Leaf & P. amurense & Rutaceae & Hebei, China & КT961053 & KT961081 \\
\hline $\mathrm{S} 12$ & Cortex & P. chinense & Rutaceae & Chongqing, China & KT961061 & KT961089 \\
\hline $\mathrm{S} 13$ & Cortex & P. chinense & Rutaceae & Chongqing, China & KT961062 & KT961088 \\
\hline $\mathrm{S} 14$ & Cortex & P. chinense & Rutaceae & Hubei, China & KT961058 & KT961085 \\
\hline S15 & Cortex & P. chinense & Rutaceae & Hubei, China & КT961059 & KT961087 \\
\hline S16 & Cortex & P. chinense & Rutaceae & Chongqing, China & KT961060 & KT961086 \\
\hline L3 & Leaf & P. chinense & Rutaceae & Beijing, China & KT961056 & KT961084 \\
\hline S17 & Cortex & P. chinense var. glabriusculum & Rutaceae & Sichuan, China & KT961063 & KT961093 \\
\hline S18 & Cortex & P. chinense var. glabriusculum & Rutaceae & Sichuan, China & KT961064 & KT961094 \\
\hline S19 & Cortex & P. chinense var. glabriusculum & Rutaceae & Sichuan, China & KT961066 & KT961092 \\
\hline S20 & Cortex & P. chinense var. glabriusculum & Rutaceae & Sichuan, China & KT961067 & KT961095 \\
\hline $\mathrm{S} 21$ & Cortex & P. chinense var. glabriusculum & Rutaceae & Sichuan, China & KT961068 & KT961096 \\
\hline $\mathrm{S} 22$ & Cortex & P. chinense var. glabriusculum & Rutaceae & Sichuan, China & KT961070 & KT961097 \\
\hline L4 & Leaf & P. chinense var. glabriusculum & Rutaceae & Beijing, China & KT961057 & KT961091 \\
\hline L5 & Leaf & P. chinense var. glabriusculum & Rutaceae & Beijing, China & KT961065 & KT961090 \\
\hline L6 & Leaf & P. chinense var. glabriusculum & Rutaceae & Sichuan, China & КT961069 & KT961098 \\
\hline $\mathrm{L} 7$ & Leaf & Tetradium ruticarpum & Rutaceae & Chongqing, China & KT961040 & KT961099 \\
\hline L8 & Leaf & Tetradium ruticarpum & Rutaceae & Chongqing, China & KT961041 & KT961100 \\
\hline L9 & Leaf & Tetradium ruticarpum & Rutaceae & Chongqing, China & KT961042 & KT961101 \\
\hline L10 & Leaf & Tetradium ruticarpum & Rutaceae & Chongqing, China & KT961043 & KT961102 \\
\hline
\end{tabular}


Table 2. The Genetic Distance of Phellodendron Genus Samples

\begin{tabular}{|c|c|c|c|c|c|}
\hline \multirow{2}{*}{ Crude drugs } & \multirow{2}{*}{ Scientific name } & \multirow{2}{*}{$\mathrm{K} 2 \mathrm{P}$ genetic distances } & \multicolumn{3}{|c|}{ Range of genetic distances (mean) } \\
\hline & & & ITS & $p s b \mathrm{~A}-t r n \mathrm{H}$ & $\mathrm{ITS}+p s b \mathrm{~A}-t r n \mathrm{H}$ \\
\hline Guanhuangbo & P. amurense & Intraspecific distances & $\begin{array}{l}0-0.0016 \\
(0.0002)^{a)}\end{array}$ & $\begin{array}{l}0-0.0047 \\
(0.0018)\end{array}$ & $\begin{array}{c}0-0.0029 \\
(0.0009)\end{array}$ \\
\hline \multirow[t]{5}{*}{ Huangbo } & & Intraspecific distances & $\begin{array}{l}0-0.0065 \\
(0.0036)\end{array}$ & $0(0)$ & $\begin{array}{l}0-0.0038 \\
(0.0021)\end{array}$ \\
\hline & P. chinense & Intraspecific distances & $\begin{array}{l}0-0.0032 \\
(0.0019)\end{array}$ & $0(0)$ & $\begin{array}{l}0-0.0019 \\
(0.0011)\end{array}$ \\
\hline & P.chinense var. glabriusculum & Intraspecific distances & $\begin{array}{l}0-0.0048 \\
(0.0030)\end{array}$ & $0(0)$ & $\begin{array}{l}0-0.0029 \\
(0.0014)\end{array}$ \\
\hline & & $\begin{array}{l}\text { Interspecific distances between Guanhuangbo } \\
\text { and Huangbo }\end{array}$ & $\begin{array}{l}0.0016-0.0049 \\
(0.0025)\end{array}$ & $\begin{array}{l}0.0141-0.0188 \\
\quad(0.0152)\end{array}$ & $\begin{array}{l}0.0067-0.0086 \\
(0.0077)\end{array}$ \\
\hline & & $\begin{array}{l}\text { Interspecific distances between } P \text {. chinense and } \\
P \text {. chinense var. glabriusculum }\end{array}$ & $\begin{array}{c}0.0032-0.0065 \\
(0.0048)\end{array}$ & $0(0)$ & $\begin{array}{l}0.0019-0.0038 \\
(0.0029)\end{array}$ \\
\hline
\end{tabular}

a) Average distance.

Biotech Co., China), $1 \mu \mathrm{L}$ of each primer $(2.5 \mu \mathrm{M})$, in a final volume of $25 \mu \mathrm{L}$. The PCR conditions of ITS were 35 cycles of denaturation at $94^{\circ} \mathrm{C}$ for $1 \mathrm{~min}$, annealing at $50^{\circ} \mathrm{C}$ for $1 \mathrm{~min}$, and extension at $72^{\circ} \mathrm{C}$ for $1.5 \mathrm{~min}(+3 \mathrm{~s} /$ cycle $)$. The PCR conditions for $p s b \mathrm{~A}-t r n \mathrm{H}$ were 30 cycles of denaturation at $94^{\circ} \mathrm{C}$ for $1 \mathrm{~min}$, annealing at $55^{\circ} \mathrm{C}$ for $1 \mathrm{~min}$, and extension at $72^{\circ} \mathrm{C}$ for $1.5 \mathrm{~min}^{14,23-25)} \mathrm{PCR}$ products were separated and detected by $1.5 \%$ agarose gelelectrophoresis. Purified products were sequenced in both directions in a 3730XL sequencer (Applied Biosystems, U.S.A.).

HPLC Methods Samples $(0.5000 \mathrm{~g})$ taken from dried cortex (sieved 65-mesh) were suspended in $50 \mathrm{~mL} 1 \%$ hydrochloric acid in methanol in a capped conical flask. They were then accurately weighed and extracted with three forty-minute ultrasonication steps. After cooling, weighing, and adding extraction solvent to compensate for the decrease in weight, the sample was mixed. The sample solution was filtered through a $0.22 \mu \mathrm{m}$ membrane filter prior to the HPLC analysis. HPLC chromatographic conditions were conducted as described by Zhang et al. ${ }^{11)}$

Statistical Analysis Sequences were assembled and aligned by the CodonCode Aligner 3.7.1 (CodonCode Co., U.S.A.). The ITS2 region was obtained using the HMMer annotation method based on the Hidden Markov model (HMM) to remove the $5.8 \mathrm{~S}$ and $28 \mathrm{~S}$ sections at both ends of the sequences. ${ }^{26)}$ The inter/intra-specific genetic distances and the bootstrap Neighbor-Joining (NJ) tree were conducted by MEGA (4.0 Version), according to Kimura's 2-parameter method with bootstrap testing of 1000 replicates. Hierarchical clustering analysis (HCA) was applied to demonstrate the variability of the relative peak areas of six bioactive compounds in 22 cortex samples of Phellodendri Cortex using SPSS (Version 19.0) and Unscrambler (Version 10.0). Principal component analysis (PCA), based on six compounds, was carried out using Unscrambler (Version 10.0).

\section{RESULTS}

Sequence Inter/Intra-Specific Variations Analysis The base sequence of the ITS2 analysis showed 100\% homology between all samples. The genetic distance of the ITS, psbA$\operatorname{trn} \mathrm{H}$ and ITS $+p s b \mathrm{~A}-\operatorname{trn} \mathrm{H}$ sequences were showed in Table 2, which was based on the K2P model calculated by MEGA5.1
Beta2. The average interspecific distance between Guanhuangbo and Huangbo was higher than their average intraspecific distance, except when the ITS sequence was used. This meant that the abilities of $p s b \mathrm{~A}-t r n \mathrm{H}$ and ITS $+p s b \mathrm{~A}-t r n \mathrm{H}$ to identify Guanhuangbo and Huangbo were superior to ITS. Moreover, the average interspecific distance of $P$. chinense and $P$. chinense var. glabriusculum was higher than their average intraspecific distance, except when the $p s b \mathrm{~A}-t r n \mathrm{H}$ sequence was used. This indicated that the ability of ITS and ITS $+p s b \mathrm{~A}-t r n \mathrm{H}$ to identify the origin of Huangbo was better than $p s b \mathrm{~A}-t r n \mathrm{H}$. In summary, ITS $+p s b \mathrm{~A}-t r n \mathrm{H}$ was the superior sequence for tracing and identifying Phellodendri Cortex.

NJ Tree Analysis An NJ tree illustrates the relationships between species and facilitates a characterization of their clustering. In this study, an NJ tree of DNA barcodes was built based on the K2P model. The NJ tree built on the ITS sequence demonstrated that $P$. amurense, $P$. chinense and $P$. chinense var. glabriusculum were short of monophyly. In the psbA-trn $\mathrm{H}$ sequence based $\mathrm{NJ}$ tree, Phellodendron genus species clustered into two clades: one was $P$. amurense and the other was $P$. chinense and $P$. chinense var. glabriusculum (Fig. 1). There was significant monophyly in the NJ tree built on the ITS $+p s b \mathrm{~A}-t r n \mathrm{H}$ sequence, where Phellodendron genus species separately clustered into three clades (Fig. 2). Thus, the NJ tree clearly distinguished between $P$. amurense, $P$. chinense and $P$. chinense var. glabriusculum as well as Guanhuangbo and Huangbo.

HPLC Fingerprints and PCA A total of 22 cortex samples were examined, and representative HPLC fingerprints were showed in Fig. 3. The chromatographic data showed that the HPLC fingerprints of $P$. amurense had clear differences from those of $P$. chinense or $P$. chinense var. glabriusculum, whereas the fingerprints of the latter two species were almost identical. The chemical marker content in the cortex of $P$. amurense was distinct from that of $P$. chinense and $P$. chinense var. glabriusculum. The level of magnoflorine and palmatine chloride in the $P$. amurense samples was markedly higher with an apparently lower level of berberine, compared to $P$. chinense or $P$. chinense var. glabriusculum. By comparing the similarities of the HPLC chromatographic fingerprints together with the relative contents of magnoflorine, palmatine chloride and berberine chloride, Guanhuangbo and Huangbo were effectively differentiated. The result of the PCA's loading 


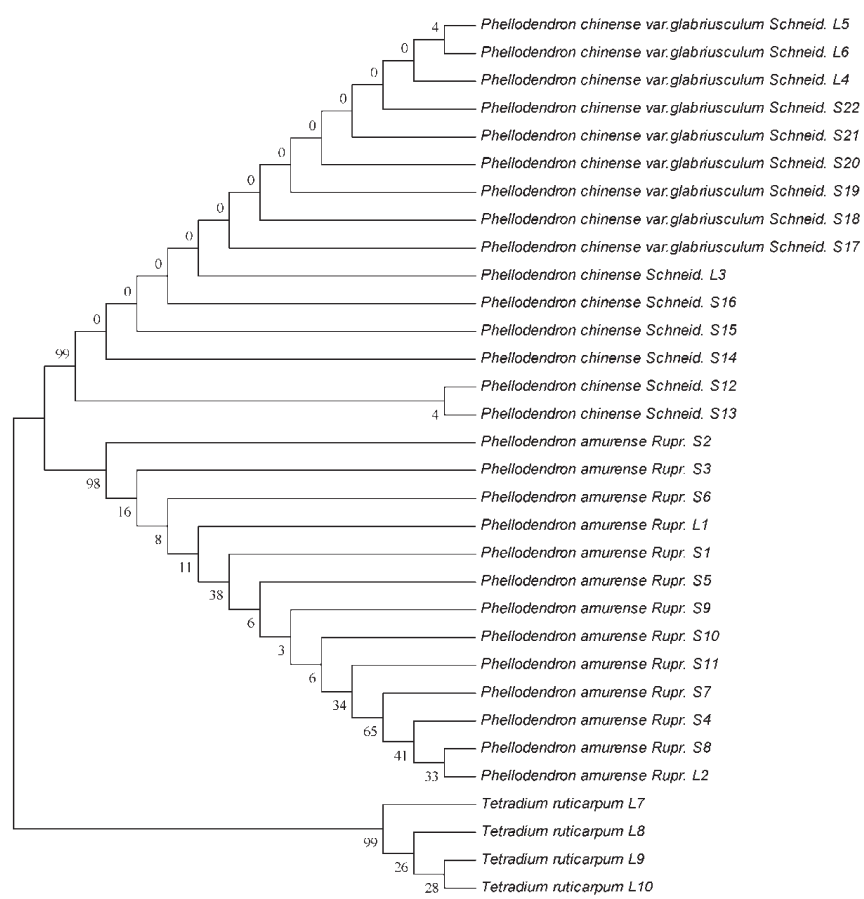

Fig. 1. The NJ Tree of the Phellodendron Genus Species with the $p s b \mathrm{~A}-t r n \mathrm{H}$ Sequence

The bootstrap scores (1000 replicates) were shown for each branch.

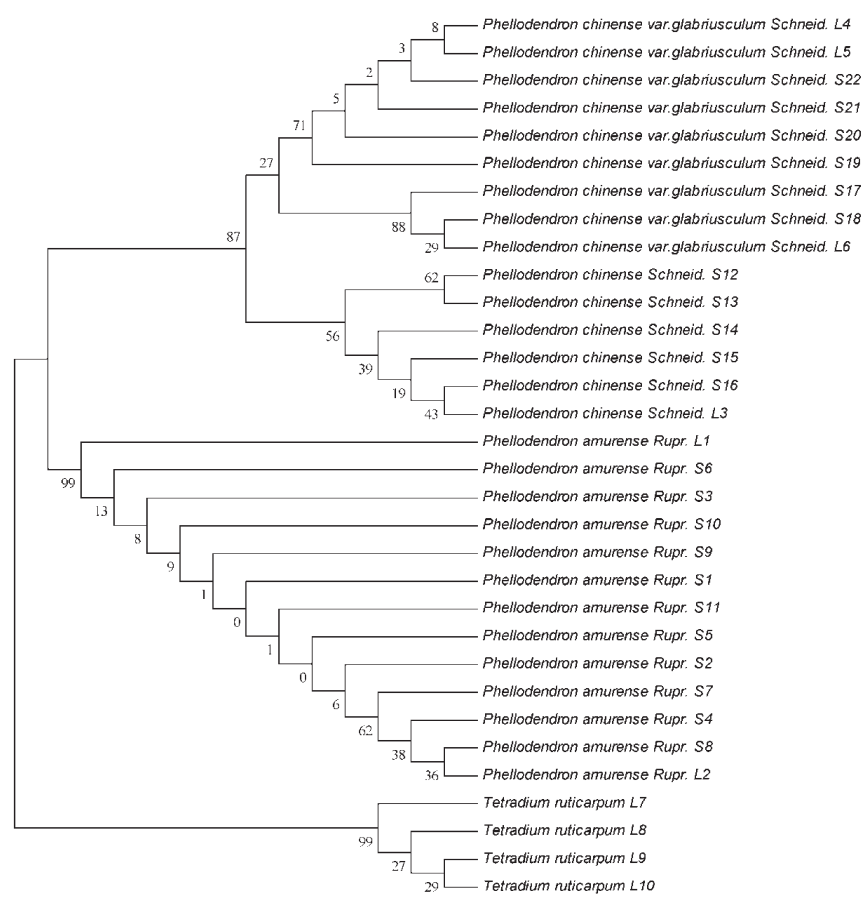

Fig. 2. The NJ Tree of the Phellodendron Genus Species with the ITS $+p s b \mathrm{~A}-t r n \mathrm{H}$ Sequence

The bootstrap scores (1000 replicates) were shown for each branch.

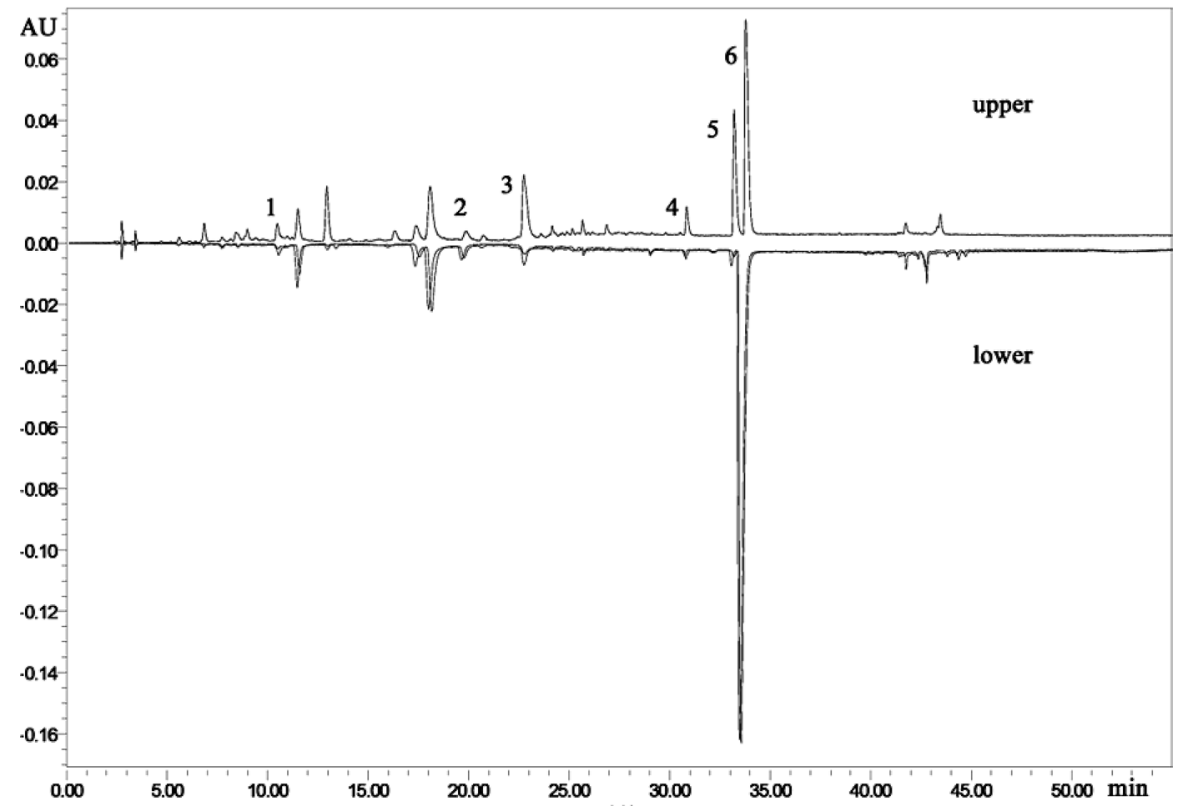

Fig. 3. HPLC Chromatographic Fingerprint Analysis of P. amurense (Upper), P. chinense, and P. chinense var. glabriusculum (Lower)

(1) Chlorogenic acid, (2) phellodendrine, (3) magnoflorine, (4) jatrorrhizine chloride, (5) palmatine chloride, (6) berberine chloride.

plot revealed that magnoflorine, palmatine chloride and berberine chloride were powerful towards distinguishing between the two crude herbs (Fig. 4C). However, because of the HPLC fingerprints for $P$. chinense and $P$. chinense var. glabriusculum were similar, the HPLC fingerprints could not be used to discriminate the two species.

HCA To validate the results of the the HPLC fingerprint analysis and to further elucidate the resemblance relationship among the samples, HCA was applied using the SPSS 19.0 software and the Unscrambler X 10.0 software. The relative peak areas of the six peaks that corresponded to chlorogenic acid, phellodendrine, magnoflorine, jatrorrhizine, palmatine and berberine were generated using the similarity analysis. The results of HCA showed that all 22 cortex samples were clearly divided into two clusters at level 1 (Figs. 4A, B). Group I was formed by all cortex samples of $P$. amurense, where as Group II consisted of all cortex samples of $P$. chinense and S17 (P. chinense var. glabriusculum) with all P. chinense samples forming one shorter cluster at level 2, indicating that $P$. chinense and $P$. chinense var. glabriusculum were similar in chemical composition. The results were consistent with the HPLC fingerprint analysis. Therefore, HCA was also 

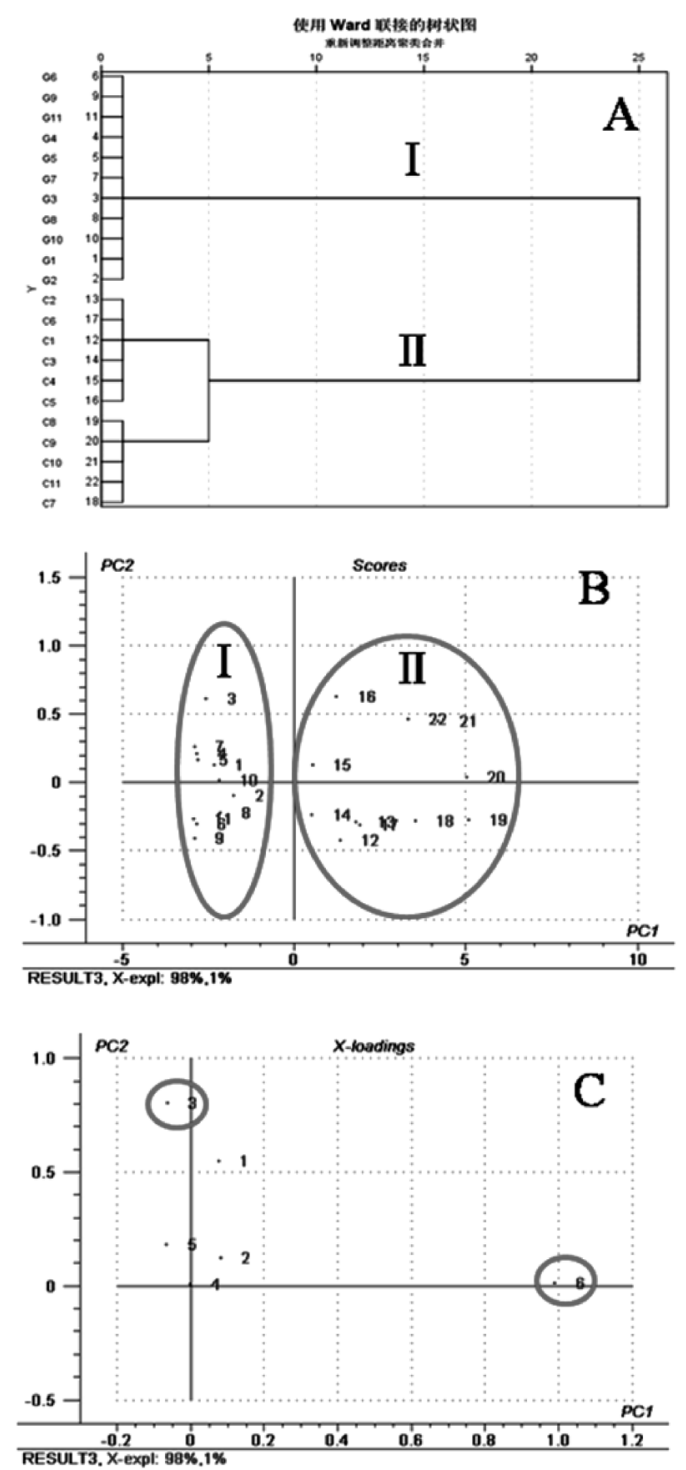

Fig. 4. HPLC Chemometrics Analysis of 22 Samples of Phellodendri Cortex

Dendrogram for hierarchical clustering by SPSS (A) and the Unscrambler (B); principle component loading plot by Unscrambler (C).

helpful towards differentiating Guanhuangbo and Huangbo but insufficient for identifying the original plants of Huangbo.

\section{DISCUSSION}

Phellodendri Cortex is a typical example of the complex, phylogenetic origin of plants. $P$. amurense is the original plant of Guanhuangbo and is distributed in northeast China, where as $P$. chinense and $P$. chinense var. glabriusculum are the original plants of Huangbo and are distributed in southwest China.) However, the crude materials of Guanhuangbo and Huangbo cannot be identified by cortex appearance, by organization structure or by their main chemical components.

DNA barcoding demonstrated an ability to universally and accurately discriminate the species in our study. The genetic distance and NJ tree analyses were assessed using DNA barcoding technology based on its ability to differentiate the Phellodendron genus species. The data supported the psbA$\operatorname{trn} \mathrm{H}$ barcode for discriminating Guanhuangbo and Huangbo
(Fig. 1) and the ITS $+p s b \mathrm{~A}-t r n \mathrm{H}$ barcode for discriminating $P$. amurense, $P$. chinense and $P$. chinense var. glabriusculum (Fig. 2). DNA barcoding successfully traced the species of Phellodendri Cortex.

Additionally, we utilized the HPLC fingerprint and HCA methods to identify three cortexes. The data showed clear differences in the HPLC fingerprints (Fig. 3) and in the HCA (Fig. 4), allowing the differentiation of Guanhuangbo and Huangbo. However, the cortexes of $P$. chinense and $P$. chinense var. glabriusculum could not be distinguished using HPLC fingerprint and HCA methods.

In summary, we have established new chemical and molecular analysis methods for discriminating Phellodendri Cortex. Our results demonstrate that DNA barcoding overcomes the limitations of the HPLC fingerprint for differentiating close genetic relationships and similar chemical-composition species to guarantee an accurate and scientific confirmation of herbal identities in medicinal materials from multiple sources.

Acknowledgment The authors are grateful for the financial support provided by the National Natural Science Foundation of China (No. 81473305).

Conflict of Interest The authors declare no conflict of interest.

\section{REFERENCES}

1) Editorial Committee of Flora Reipublicae Popularis Sinicae. Flora of Reipublicae Populars Sinicae. Angiospermae, Dicotyledoneae, Rutaceae. China Science Press, Beijing, Vol. 42, pp. 99-103 (1997).

2) Wu JR, Zhang B, Zhang GM. Advances in the pharmacological effects of Phellodendri Cortex. Asia-Pac. Tradit. Med., 5, 160-162 (2009).

3) Jung HW, Jin G-Z, Kim SY, Kim YS, Park Y-K. Neuroprotective effect of methanol extract of Phellodendri Cortex against 1-methyl4-phenylpyridinium (MPP+)-induced apoptosis in PC-12 cells. Cell Biol. Int., 33, 957-963 (2009).

4) National Pharmacopoeia Committee. Pharmacopoeia of the People's Republic of China, Part I. China Medical Science Press, Beijing (2000).

5) State Bureau of Environmental Protection of China \& Institute of Botany Chinese Academy of Sciences. The list of chinese rare and endangered plants. China Science Press, Beijing, p. 22 (1987).

6) National Pharmacopoeia Committee. Pharmacopoeia of the People's Republic of China, Part I. China Medical Science Press, Beijing (2005).

7) National Pharmacopoeia Committee. Pharmacopoeia of the People's Republic of China, Part I. China Medical Science Press, Beijing (2010).

8) Wang L, Zhang XR, Xing LM. Measuring the content of berberine in Huangbai by TLC. J. Shaanxi Colg. Tradit. Chin. Med., 21, 36 (1998).

9) Yang GD, He LC, Du J, Liu J. Simultaneous determination berberine hydronchloride and palmatine hydrochloride in Cortex Phellodendri chinensis by capillary electrophoresis. Chin. Pharm. J., 40, 1343 (2005).

10) Zhang SH, Guo WW, Cai GX. Studies of cortex Phellodendri amuren on HPLC fingerprint and genealogied cluster analysis. Sci. \& Technol. Rev, 24, 51 (2005).

11) Zhang Y, Zhang ZP, Liu HT, Zhang BG, Liao YH, Zhang Z. Quantitative and chemical fingerprint analysis for quality evaluation of the dried bark of wild Phellodendron amurense Rupr. based on HPLC-DAD-MS combined with chemometrics methods. Anal. 
Methods, 7, 2041-2049 (2015)

12) Ryuk JA, Zheng MS, Lee MY, Seo CS, Li Y, Lee SH, Moon DC, Lee HW, Lee JH, Park JY, Son JK, Ko BS, Ko BS. Discrimination of Phellodendron amurense and $P$. chinense based on DNA analysis and the simultaneous analysis of alkaloids. Arch. Pharm. Res., 35, 1045-1054 (2012).

13) Li DZ, Liu JQ, Chen ZD, Wang H, Ge XJ, Zhou SL, Gao LM, Fu CX, Chen SL. Plant DNA barcoding in China. J. Syst. Evol., 49, 165-168 (2011)

14) Hollingsworth PM, Forrest LL, Spouge JL, Hajibabaei M, Ratnasingham S, van der Bank M, Chase MW, Cowan RS, Erickson DL, Fazekas AJ, Graham SW, James KE, Kim K-J, Kress WJ, Schneider H, van AlphenStahl J, Barrett SCH, van den Berg C, Bogarin D, Burgess KS, Cameron KM, Carine M, Chacon J, Clark A, Clarkson JJ, Conrad F, Devey DS, Ford CS, Hedderson TAJ, Hollingsworth ML, Husband BC, Kelly LJ, Kesanakurti PR, Kim JS, Kim Y-D, Lahaye R, Lee H-L, Long DG, Madrinan S, Maurin O, Meusnier I, Newmaster SG, Park C-W, Percy DM, Petersen G, Richardson JE, Salazar GA, Savolainen V, Seberg O, Wilkinson MJ, Yi D-K, Little DP, CBOL Plant Working Group. A DNA barcode for land plants. Proc. Natl. Acad. Sci. U.S.A., 106, 12794-12797 (2009).

15) Li DZ, Gao LM, Li HT, Wang H, Ge XJ, Liu JQ, Chen ZD, Zhou SL, Chen SL, Yang JB, Fu CX, Zeng CX, Yan HF, Zhu YJ, Sun YS, Chen SY, Zhao L, Wang K, Yang T, Duan GW, Chinese Plant BOL Group. Comparative analysis of a large dataset indicates that internal transcribed spacer (ITS) should be incorporated into the core barcode for seed plants. Proc. Natl. Acad. Sci. U.S.A., 108, 19641-19646 (2011).

16) Xin TY, Li XJ, Yao H, Lin YL, Ma XC, Cheng RY, Song JY, Ni LH, Fan CZ, Chen SL. Survey of commercial Rhodiola products revealed species diversity and potential safety issues. Sci. Rep., 5, 8337 (2015)

17) Chun HC, Tsong AY. Molecular authentication of Dendrobium species by multiplex polymerase chain reaction and amplification refractory mutation system analysis. J. Am. Soc. Hortic. Sci., 137, 438-444 (2012)

18) Yu H, Wu KY, Song JY, Zhu YJ, Yao H, Luo K, Dai Y, Xu SJ, Lin YL. Expedient identification of Magnoliaceae species by DNA barcoding. Plant Omics J., 7, 47-53 (2014).

19) Chen XC, Liao BS, Song JY, Pang XH, Han JP, Chen SL. A fast SNP identification and analysis of intraspecific variation in the medicinal Panax species based on DNA barcoding. Gene, 530, 39-43 (2013).

20) $\overline{\mathrm{Gao}} \mathrm{T}, \mathrm{Ma} \mathrm{XY}$, Zhu XZ. Use of the $p s b \mathrm{~A}-\operatorname{trn} \mathrm{H}$ region to authenticate medicinal species of Fabaceae. Biol. Pharm. Bull., 36, 1975-1979 (2013)

21) Guo XR, Wang XG, Su WH, Zhang GF, Zhou R. DNA Barcodes for discriminating the medicinal plant Scutellaria baicalensis (Lamiaceae) and its adulterants. Biol. Pharm. Bull., 34, 1198-1203 (2011).

22) Ma XY, Xie CX, Liu C, Song JY, Yao H, Luo K, Zhu YJ, Gao T, Pang XH, Qian J, Chen SL. Species identification of medicinal pteridophytes by a DNA barcode marker, the chloroplast $p s b \mathrm{~A}-t r n \mathrm{H}$ intergenic region. Biol. Pharm. Bull., 33, 1919-1924 (2010).

23) Chen SL, Yao H, Han JP, Liu C, Song JY, Shi LC, Zhu YJ, Ma XY, Gao T, Pang XH, Luo K, Li Y, Li XW, Jia XC, Lin YL, Leon C. Validation of the ITS2 region as a novel DNA barcode for identifying medicinal plant species. PLoS ONE, 5, e8613 (2010).

24) Kress WJ, Wurdack KJ, Zimmer ER, Weigt LA, Janzen DH. Use of DNA barcodes to identify flowering plants. Proc. Natl. Acad. Sci. U.S.A., 102, 8369-8374 (2005).

25) Li M, Au KY, Lam H, Cheng L, Jiang RW, But PP, Shaw PC. Identification of Baiying (Herba Solani lyrati) commodity and its toxic substitute Xungufeng (Herba Aristolochiae mollissimae) using DNA barcoding and chemical profiling techniques. Food Chem., 135, 1653-1658 (2012)

26) Keller A, Schleicher T, Schultz J, Muller T, Dandekar T, Wolf M. 5.8S-28S rRNA interaction and HMM-based ITS2 annotation. Gene, 430, 50-57 (2009) 